Review

\title{
Non-Coding RNAs and Cancer
}

\author{
Federica Calore $^{\dagger}$, Francesca Lovat ${ }^{\dagger}$ and Michela Garofalo * \\ Department of Molecular Virology, Immunology and Medical Genetics, \\ Comprehensive Cancer Center, Ohio State University, Columbus, OH 43210, USA; \\ E-Mails: federica.calore@osumc.edu (F.C.); francesca.lovat@osumc.edu (F.L.) \\ $\dagger$ These authors contributed equally to this work. \\ * Author to whom correspondence should be addressed; E-Mail: michela.garofalo@osumc.edu; \\ Tel.: +1-614-688-8056; Fax: +1-614-292-4097.
}

Received: 5 July 2013; in revised form: 1 August 2013 / Accepted: 8 August 2013 /

Published: 19 August 2013

\begin{abstract}
The discovery of the biological relevance of non-coding RNA (ncRNAs) molecules represents one of the most significant advances in contemporary molecular biology. Expression profiling of human tumors, based on the expression of miRNAs and other short or long ncRNAs, has identified signatures associated with diagnosis, staging, progression, prognosis, and response to treatment. In this review we will discuss the recent remarkable advancement in the understanding the biological functions of human ncRNAs in cancer, the mechanisms of expression and the therapeutic potential.
\end{abstract}

Keywords: small non-coding RNAs; long non-coding RNAs; cancer

\section{Introduction}

The human genome sequencing performed by the International Human Genome Sequencing Consortium revealed that the number of protein-coding genes corresponded only to 20-25,000 [1]. While, at first, it was common belief that the remaining, bigger portion of the human genome was not functional and considered as "junk DNA", several studies based on advanced technologies such as tiling arrays and RNA deep sequencing have recently pointed out the identification of thousands of RNA transcripts not derived from known genes and not encoding for a protein [2,3]. These molecules have been classified as non-coding RNAs (ncRNAs). 
NcRNAs could be grouped into two major classes based on the transcript size: small ncRNAs less than $200 \mathrm{bp}$, such as piRNAs (Piwi-associated RNAs), miRNAs (microRNAs), and snoRNAs (small nucleolar RNAs), and long ncRNAs (lncRNAs), greater than $200 \mathrm{bp}$. Each of these classes can be further divided, whereas novel subclasses are still being discovered and characterized. All these ncRNAs form huge molecular networks and play a central role in regulating cellular activities in Eukaryotes. The alteration and dysregulation of several ncRNA has been reported in various human diseases, including cancer, providing evidence for targeting these molecules as anticancer agents. Here, we will summarize the current knowledge about regulatory functions of ncRNAs, with special emphasis on their effects in cancer formation and progression.

\section{2. piRNAs}

PIWI-family proteins and their associated small RNAs (piRNAs) provide an essential protection for germ-cell genomes against the activity of transponsable elements (TE). They help to maintain genome integrity, silencing TE [4] and this role is highly conserved across animal species. Unlike the other classes of small noncoding RNAs, which are 24-32 nt in length, they are generated from single-stranded RNA precursors through a Dicer-independent mechanism [5-7]. PiRNAs associate with PIWI proteins, which are germline-specific members of the Argonaute protein family, while siRNAs and miRNAs associate with ubiquitously expressed AGO subfamily members. The PIWI protein family is highly conserved across a variety of species and organisms. MIWI, MILI, and MIWI2 (Piwil4) are the three mouse PIWI proteins [8-10], whereas PIWIL1/HIWI, PIWIL2/HILI, PIWIL3, and PIWIL4/HIWI2 are the four PIWI proteins expressed in humans [11]. PIWI mutations in mice, Drosophila, and zebrafish, result in consistent defects in spermatogenic cells, demonstrating the essential role of PIWI proteins in germline development [12-15]. PiRNAs are more expressed in testes than other small noncoding RNAs [16-19] and are involved in spermatogenesis by regulating meiosis and/or suppressing TE. Hundreds of thousands of different piRNA species have been found in mammals [20], with no clear secondary structure motifs but with a common bias $5^{\prime}$ uridine. At $3^{\prime}$ termini piRNAs present a $2^{\prime}-O$-methylation, a process mediated by methyltransferase HEN1, which is associated with PIWI proteins [21,22]. This modification protects piRNA from $3{ }^{\prime} \rightarrow 5^{\prime}$ exonucleases activity, suggesting an increase of their stability [23]. PiRNAs are not distributed across the whole genome but they are clustered in few hundred genomic loci called piRNA clusters [6]. The biogenesis of piRNA could be divided into two main pathways: primary processing and ping-pong amplification cycle (Figure 1). First, piRNA clusters are transcribed in both directions and provide a pool of fragmented primary piRNAs. Primary piRNA transcripts are exported to the cytoplasm where numerous factors (i.e., Zucchini, Armitage and YB) participate in piRNA processing and loading onto PIWI proteins [24,25]. Piwi-piRNA complexes are transported into the nucleus, where they inhibit transcription of TE $[26,27]$. This first process (primary processing) is similar between germline and somatic cells. The next phase, the ping-pong amplification, is restricted to germline cells and requires slicer activity of PIWI proteins [25,26]. Recently, few works have demonstrated, by deep sequencing, that piRNA population is present in many more cell types than germline cells. For example, Lee et al. indentified the presence of a limited set of piRNAs in the mouse hippocampus. The most up-regulated, DQ541777, controls spine shape [28]. Moreover, another study described piRNA expression in more 
than 130 fruit fly, mouse, and rhesus macaque samples. Further, in mouse pancreas and macaque epididymis, piRNA are abundant as much as piRNA abundance in the germline [29]. An emerging number of studies highlights the role of piRNAs or PIWI proteins in the regulation of tumorigenesis. Indeed, piRNAs have been described in HeLa cells [30] and gastric, colon, lung, and breast cancer tissues [31]. These discoveries should not be surprising considering that cancer cells and germ cells share common features such as rapid proliferation and potentially infinite self-renewal. The first evidence of the role of piRNAs in cancer is described by Qiao et al. Hiwi, a Piwi family member, is over-expressed in seminomas but not in nonseminomas or in somatic tumors of the adult testis [32]. Moreover, HIWI over-expression has been also shown in cervical, pancreatic, colorectal, endometrial, esophageal, liver cancer, and gliomas [33-39]. Recently, Cheng and colleagues demonstrated that the expression of piR-651 in gastric, colon, lung, and breast cancer tissues was higher compared to normal adjacent tissues. The levels of piR-651 were associated with tumor-node-metastasis (TNM) stages. Inhibition of piR-651 caused the arrest of gastric cancer cells at the $\mathrm{G}_{2} / \mathrm{M}$ phase [31]; therefore this pi-RNA shows an oncogenic role and plays a crucial function in carcinogenesis. Another study demonstrated the down-regulation of piR-823 in gastric cancer tissues compared to normal tissues suggesting its potential tumor suppressive role [40]. In vivo studies showed that the over-expression of $p i R-823$ significantly inhibited tumor growth in a dose-dependent manner. Moreover, piR- 823 was significantly lower in peripheral blood of gastric cancer patients compared to healthy controls. The levels of piR-823 were positively associated with TNM stages and distant metastasis, suggesting that piR-823 should be tested as a biomarker for detecting circulating gastric cancer cells in the blood [41]. All these data may suggest an important role of the axis PIWI and PIWI-associated RNAs going beyond the regulation of the genome in germline tissues and more studies are needed in order to investigate their specific role in tumorigenesis.

\section{MicroRNAs}

In 1993, Victor Ambros and colleagues discovered a gene, lin-4, that affected the development of Caenorhabditis elegans and found that its product was a small nonprotein-coding RNA [42]. The number of known small RNAs in different organisms such as Caenorhabditis elegans, Drosophila melanogaster, plants, and mammals, including humans, has since expanded substantially. MicroRNAs (miRNAs) are 19- to 24- nucleotide non-coding RNA molecules that regulate the expression of target mRNAs both at the transcriptional and translational level $[43,44]$. While in plants such regulation occurs through perfect base-pairing, usually in the $3^{\prime}$ untranslated region (UTR) of the targeted mRNA, in mammals the base-pairing is only partial $[45,46]$.

Each member of this large family of non-coding RNAs can have hundreds of different targets and nearly $30 \%$ of the genes are regulated by, at least, one miRNA [43]. Several studies have demonstrated the involvement of miRNAs in different biological processes such as proliferation, cell cycle regulation, proliferation, apoptosis, differentiation, development, metabolism, neuronal patterning, and aging [43-53]. 
Figure 1. PiRNAs and microRNAs biogenesis. On the left, piRNAs biogenesis. PiRNAs are processed from single-stranded RNA precursors. The biogenesis of piRNAs could be divided in two main pathways: primary processing and ping-pong amplification cycle. MIWI2, a PIWI protein, translocates processed piRNAs into the nucleus, where they block the transcription of the TE (trasposon elements). On the right, miRNA biogenesis. Primary transcripts (pri-miRs) are transcribed by the RNA polymerase II. In the nucleus pri-miRs are processed by Drosha-DGCR 8 into pre-miRs of $\sim 60-70 \mathrm{nt}$. The produced pre-miRNAs are exported by the Exportin 5 to the cytoplasm where they are processed in 18-22-nucleotide miRNA duplexes by the cytoplasmic RNase III Dicer. Normally, one strand of this duplex is degraded, whereas the other strand accumulates as a mature miRNA. From the miRNA-miRNA duplex, only the miRNA enters preferentially in the protein effector complex, formed by the RNA-induced silencing complex (RISC) and miRgonaute. Perfect or nearly perfect complementarities between miRNA and its target 3' UTR induce RISC to cleave the target mRNA, whereas imperfect base matching induces mainly translational silencing of the target.

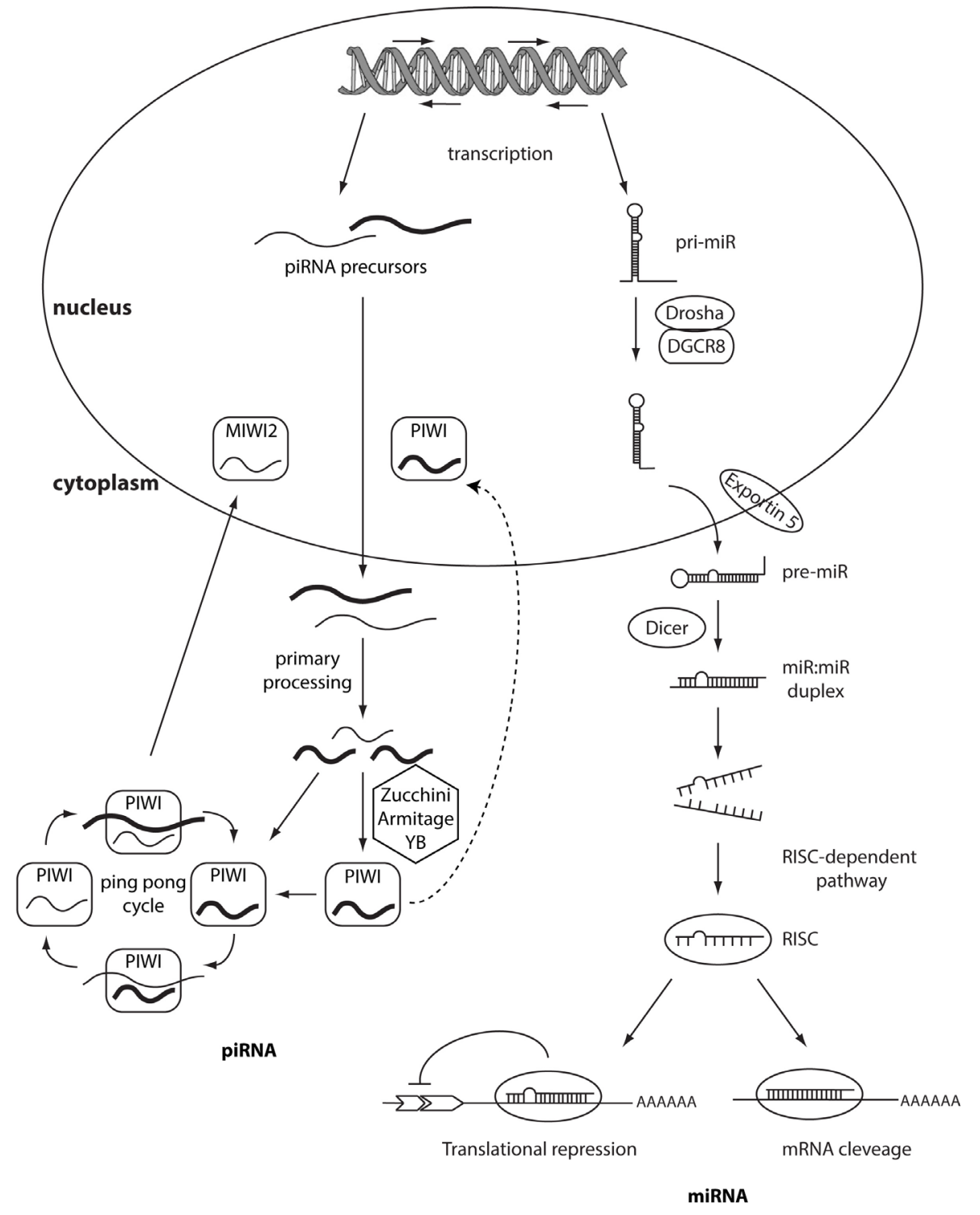


MiRNAs are transcribed by an RNA polymerase II as long, capped and polyadenylated precursors called pri-miRNAs [54,55], which are further cleaved into hairpin-shaped $\sim 70-100$ nucleotides precursors (pre-miRNAs) by a ribonuclease III (Drosha) and the double-stranded DNA binding protein DGCR8/Pasha [56] (Figure 1). Exportin 5 then translocates the pre-miRNAs to the cytoplasm [57], where another RNAse III, Dicer [43,58] further processes the precursor in a double strand RNA of about 24 nt. The double-stranded RNA is incorporated into the RISC (RNA-induced silencing complex) but only one strand, the mature microRNA, remains stably associated with the RISC and will drive the complex to the target mRNA. If the base-pairing between miRNA and the 3' UTR of the target mRNA is perfect the messenger is cleaved and degraded, whereas imperfect complementarity will result in translational silencing without mRNA degradation [59,60]. Several studies have demonstrated that miRNAs have a crucial role in cancer formation and spread. These small non-coding RNAs are, in fact, usually located in minimal regions of amplification, loss of heterozygosity, fragile sites, and common breakpoint regions in or in proximity of oncogenes or tumor suppressor genes. Moreover, profiling studies have demonstrated that miRNAs are differentially expressed in tumors $v s$. normal human tissues. These data have allowed the classification of microRNAs into two groups: oncomiRs (which act as oncogenes and are usually overexpressed in cancer, promoting tumor formation and spread) and tumor-suppressor miRs (which impair tumor growth and are usually silenced because of mutations, promoter methylation, or chromosomal rearrangements) [61-64], although some microRNAs can act as both oncogene or tumor-suppressor gene depending on the cellular context [65] (Figure 2 and Table1).

Figure 2. OncomiRs and tumor suppressor miRs. Correct cellular homeostasis is driven by a proper balance between oncomiRs and tumor suppressor miRs. OncomiRs are usually located in the amplified regions of the genome and are frequently over-expressed in cancer, promoting tumor growth and metastasis. Tumor suppressor miRs are often down-regulated in cancer and inhibit tumor growth inducing apoptosis and blocking cell migration.

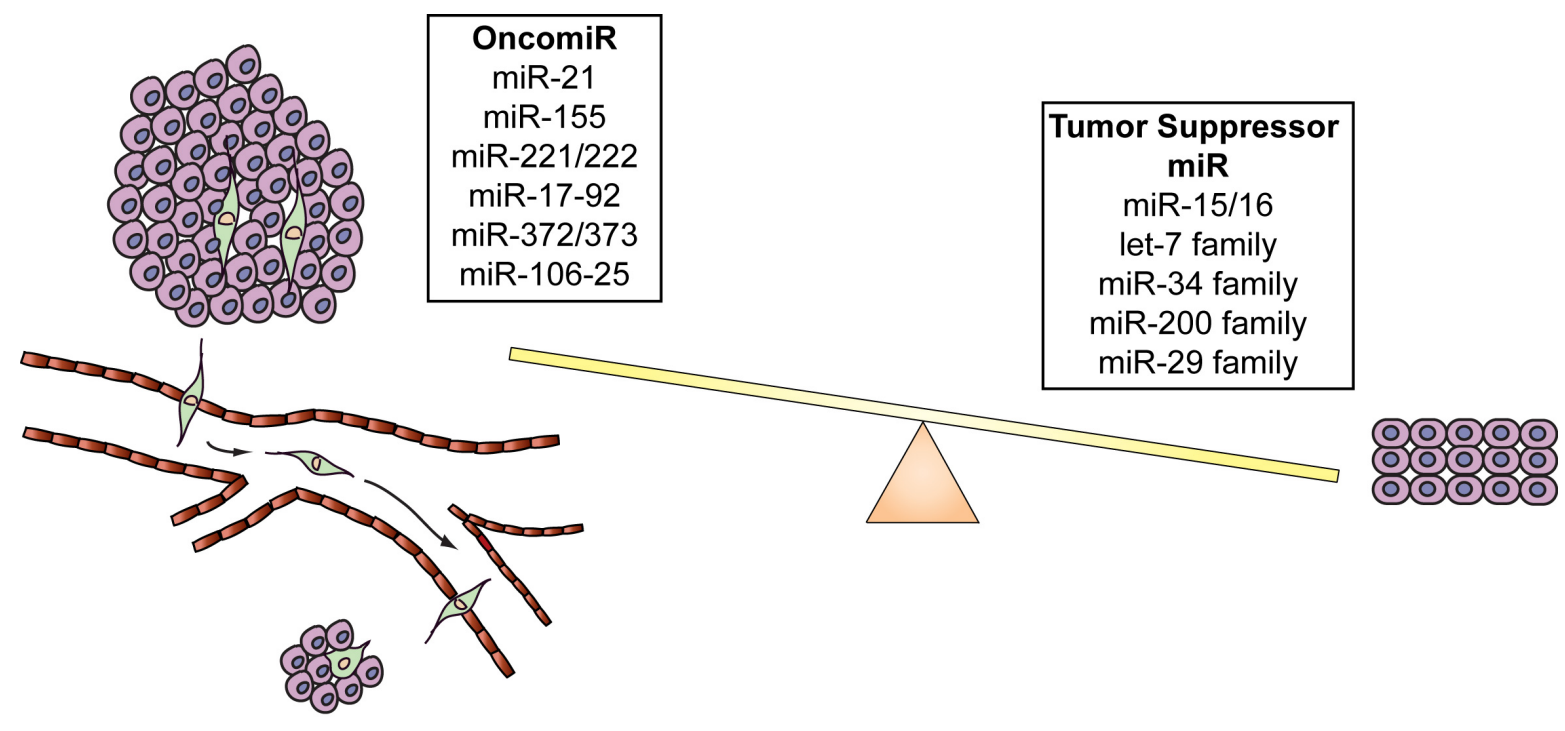




\subsection{OncomiRs}

One of the most well-known oncomiRs is $m i R-21$, overexpressed in different types of cancer such as chronic lymphocytic leukemia (CLL) [62], acute myelogenous leukemia (AML) [66], glioblastoma [67], pancreatic, prostate, colon, gastric, breast, and lung cancer [68]. In 2008, Asangani and coworkers [69] demonstrated that miR-21 downregulated the tumor suppressor PCDC4 (programmed cell death 4) promoting tumor invasion and metastasis in colorectal cancer. Zhang and colleagues [70] showed that miR-21 induced growth and invasion in non-small cell lung cancer by repressing PTEN (phosphatase and tensin homolog); moreover, miR-21 modulate TRAIL sensitivity in glioma cells mainly by modulating caspase- 3 and TAp63 expression and TRAIL-induced caspase machinery [71], confirming that $m i R-21$ acts like an oncogene by blocking the expression of critical apoptosis-related genes.

Another example of oncomiR is represented by $m i R-155$. Similarly to $m i R-21, m i R-155$ is highly expressed in CLL [72], AML [73], lung, breast and pancreatic cancer [68], Hodgkin disease [72], and primary mediastinal non-Hodgkin's lymphoma [62]. In 2010, Jiang and coworkers demonstrated that miR-155 targeted the tumor suppressor gene Socs 1 (suppressor of cytokine signaling 1 gene) in human breast cancer cells, promoting cell proliferation, colony formation, and xenograft tumor growth [74]. MiR-155 has also been found to be one of the most potent miRNAs suppressing apoptosis in human $\mathrm{T}$ cell leukemia (Jurkat cells) and in MDA-MB-453 breast cancer cells [75]. Moreover, in a transgenic mouse model, selective overexpression of $m i R-155$ in $\mathrm{B}$ cells led to early $\mathrm{B}$ cells polyclonal proliferation with a high-grade lymphoma-pre-B leukemia, suggesting that $m i R-155$ promotes the initiation and progression of the disease [76].

MiR-221 and -222 are also up-regulated in several solid tumors, such as hepatocarcinoma [77], breast estrogen negative cells [78], melanoma cells [79], thyroid cancer [80]. Both these miRNAs induce tumor growth and spread of several cancer cell lines [81-83]. In 2009, our group demonstrated that hepatocyte growth factor receptor (MET) oncogene, through Jun transcriptional activation, upregulated miR-221 and -222 expression, which in turn, by targeting PTEN and TIMP3, conferred resistance to tumor necrosis factor-related apoptosis-inducing ligand (TRAIL)-induced cell death and enhanced tumorigenicity of lung and liver cancer cells. Therefore, the use of microRNAs in therapeutic intervention could sensitize tumor cells to drug-inducing apoptosis and also inhibit their survival, proliferation, and invasive abilities [84].

The oncomiR group is wide, and comprises other microRNAs such as the miR-17-92 cluster, which is crucial for B-cell proliferation and its absence induces an increase of the proapoptotic protein Bim and inhibits the pro-B to pre-B cell development [85]; miR-372/373, which are involved in the development of human testicular germ cell tumors by neutralizing the TP53 pathway [86]; miR-10b, which promotes cell migration and invasion in breast cancer [87]; the polycistron miR-106-25, which acts as an oncogene by interfering with the synthesis of p21 and Bim [88].

\subsection{Tumor Suppressor MicroRNAs}

The group of miRNAs able to inhibit cell growth, induce apoptosis, and block cell cycle, are called tumor suppressor miRs. Normally, oncomiRs are located mainly in the amplified regions in human 
cancers and are frequently over-expressed in neoplastic tissues. Conversely, tumor suppressor miRs are located in the deleted regions and are often down-regulated in cancerous tissues.

The first evidence that miRNAs are involved in cancer comes from the finding that $m i R-15$ and miR-16 are down-regulated or deleted in most patients with chronic lymphocytic leukemia [61].

Their expression is inversely related to several oncogenes, such as Bcl-2 [89], CCND1, WNT3A [90], Ccne1, Bmi-1 [91], and VEGF-A [92], which induce cell proliferation, survival, invasion and angiogenesis. Recently it has been shown that $m i R-15$ and -16 are involved in drug resistance. Pouliot et al. demonstrated that $m i R-15$ and -16 sensitized cisplatin-resistant epidermoid carcinoma cells to apoptosis by targeting WEE1 and CHK1 [93].

Another example of tumor suppressor miR is represented by the let-7 family. Several studies described the down-regulation of let-7 family in numerous tumors, including lung [94], gastric [95], colon cancer [96], and Burkitt's lymphoma [97]. Let-7 family targets and inhibits the expression of several oncogenes such as $c-M y c$ [97], Ras [98], high-mobility group A (HMGA) [99], Janus protein tyrosine kinase $(J A K)$ and signal transducer and activator of transcription 3 (STAT3) pathway [100]. A recent study also reported that let-7 directly targets $P A K 1, D I A P H 2, R D X$, and ITGB8, multiple genes involved in the actin cytoskeleton pathway, inhibiting breast cancer cell migration [101].

The tumor suppressor activity of miR-34 family has been demonstrated in cancer cell types of lung [102], liver [103], breast [104], colon [105], brain [106], ovary [107], esophagus [108], and the lymphoid system [109]. In mammals, miR-34 family comprises three processed miRNAs that are encoded by two different genes: $m i R-34 a$ is encoded by its own transcript, whereas $m i R-34 b$ and $-34 c$ share a common primary transcript. Their expression is directly induced by p53 in response to DNA damage or oncogenic stress [110]. MiR-34 family inhibits many different oncogenic pathways involved in the control of cellular proliferation, cell cycle, and senescence by targeting oncogenes such as mitogen-activated protein kinase kinase 1 (MEK1, MAP2K1), R-Ras (RRAS), platelet-derived growth factor receptors (PDGFRA and PDGFRB) [111], and hepatocyte growth factor receptor (MET), $B C L 2$ and survivin.

$M i R-200$ family is commonly lost in aggressive tumors such as lung, prostate and pancreatic cancer. It has been shown that $m i R-200$ family members directly target ZEB1 and ZEB2, transcriptional repressors of E-cadherin [112], and BMI1, reducing epithelial mesenchimal transition [113].

$M i R-29 S$ are also downregulated in multiple cancer types such as CLL [62], breast [114] and cervical cancer [115], and hepatocellular carcinoma [116]. MiR-29 family targets and inhibits DNMT3A and $-3 B$ (DNA methyltransferases 3A and 3B) [117], Tcll in chronic lymphocytic leukaemia [118] and Mcll in cholangio-carcinoma [119]. Moreover, it has been demonstrated that the down-regulation of miR-29 by MYC, HDAC, and EZH2 promotes cell survival and growth in MYC-associated lymphomas [120]. In conclusion, the correct cell homeostasis and survival are driven by a proper balance between oncomiRs and tumor suppressor miRs. Up-regulation of oncomiRs or down-regulation of tumor suppressor miRs leads to cancer formation and progression (Figure 2 and Table 1). 
Table 1. OncomiRs and tumor suppressor miRs.

\begin{tabular}{|c|c|c|c|}
\hline miRNA & Tumor type & Status & References \\
\hline$m i R-21$ & $\begin{array}{l}\text { CLL, AML, glioblastoma, pancreatic, prostate, } \\
\text { colon, gastric, breast and lung cancer }\end{array}$ & Up-regulated & {$[62,66-71]$} \\
\hline$m i R-155$ & $\begin{array}{l}\text { CLL, AML, lung, breast and pancreatic cancer, } \\
\text { Hodgkin disease, primary mediastinal } \\
\text { non-Hodgkin's lymphoma }\end{array}$ & Up-regulated & {$[62,66,68,72,74-76]$} \\
\hline$m i R-221 / 222$ & $\begin{array}{l}\text { hepatocarcinoma, breast cancer, melanoma, } \\
\text { thyroid cancer and glioma }\end{array}$ & Up-regulated & [77-84] \\
\hline$m i R-17-92$ & AML & Up-regulated & {$[85]$} \\
\hline$m i R-372 / 373$ & testicular germ cell tumor & Up-regulated & {$[86]$} \\
\hline$m i R-10 b$ & breast cancer & Up-regulated & [87] \\
\hline$m i R-106-25$ & gastric cancer & Up-regulated & [88] \\
\hline$m i R-15-16$ & $\begin{array}{l}\text { CLL, prostate and ovarian cancer and } \\
\text { multiple myeloma }\end{array}$ & Down-regulated & {$[61,89-93]$} \\
\hline let-7 family & $\begin{array}{l}\text { lung, gastric, colon, breast cancer and } \\
\text { Burkitt's lymphoma }\end{array}$ & Down-regulated & [94-101] \\
\hline$m i R-34$ & $\begin{array}{l}\text { lung, liver, breast, colon, brain, ovary, } \\
\text { esophageal cancer and non-small cell lung } \\
\text { cancer (NSCLC) }\end{array}$ & Down-regulated & {$[102-111]$} \\
\hline$m i R-200$ & $\begin{array}{l}\text { lung, prostate and } \\
\text { pancreatic cancer }\end{array}$ & Down-regulated & {$[112,113]$} \\
\hline$m i R-29$ & $\begin{array}{l}\text { CLL, breast and cervical cancer hepatocellular } \\
\text { and cholangio-carcinoma }\end{array}$ & Down-regulated & {$[62,114-120]$} \\
\hline
\end{tabular}

\section{4. snoRNAs}

Small nucleolar RNAs (snoRNAs) are small non-coding RNAs whose length ranges from 60 to 300 nucleotides. SnoRNAs are normally located within introns of protein-coding genes and are transcribed by RNA polymerase II, but in some cases they can be found within introns of IncRNAs [121,122]. Within the cell, snoRNAs specifically accumulate in the nucleolar compartment, where they are responsible of the 2'-O-ribose methylation and pseudouridylation of specific ribosomal RNA nucleotides, essential modifications for the efficient and accurate production of the ribosome [123].

SnoRNAs can be classified into two groups: H/ACA box and C/D box. In both cases, snoRNAs hybridize specifically to the complementary sequence in the rRNAs and the associated protein complexes (C/D or H/ACA snoRNP) carry out the appropriate modification on the nucleotide that is identified by snoRNAs [124-126].

The H/ACA box snoRNAs family is involved in pseudouridylation of rRNAs. These ncRNAs have two major hairpin elements, connected by a hinge, and followed by a short tail region containing the conserved $\mathrm{H}$ and ACA box motifs that are located at the bases of the $5^{\prime}$ and $3^{\prime}$, respectively. The sequence specificity for the pseudouridylation is carried by two short antisense elements located in an internal loop of the 5' and/or 3' hairpins [127].

The C/D box snoRNAs, instead, are mainly involved in the 2'-O-methylation of rRNAs. This group of ncRNAs contains two short sequence motifs, box C (5'-PuUGAUGA-3') and box D (5'-CUGA-3') 
located near the $5^{\prime}$ and the $3^{\prime}$ ends, respectively. These elements form a terminal stem-box structure, involving not only elements required for snoRNAs nuclear localization, but also another copy of the box $\mathrm{C}$, named box C', in their central portion, and another box D, named box D'. 2'-O-methylation is carried out through one or two antisense elements located upstream box D and/or box D' and complementary to a site of rRNA 2'-O-ribose methylation [128]. The process of snoRNAs maturation has not been entirely unveiled, however it has been demonstrated that the maturation of box $\mathrm{C} / \mathrm{D}$ snoRNAs in yeast can occur through two pathways (Figure 3) [129]. In the first pathway, splicing of a pre-mRNA leads to a snoRNA-containing lariat, which is then linearized by the enzyme Dbrlp. Thanks to the activity of endonucleases and exonucleases the mature snoRNA is finally released. The second pathway, instead, is splicing-independent: the snoRNA is excided from the intron of the pre-mRNA directly, leading to the destruction of the mRNA. However, this latter pathway is still not well defined and the enzymes involved in this process have not been totally identified.

Although the main function of snoRNAs seems to be related to rRNA folding and stabilization, recent discoveries have pointed out a wider regulatory function for these small ncRNAs. For example, snoRNAs seem to be involved in miRNA synthesis. In 2010, Breimer and coworkers identified several box C/D sno-miRNAs, originating from relatively short snoRNAs (such as U27 and HBII-336) displaying miRNA features in mRNAs silencing in different cell types, therefore controlling several biological processes normally regulated by miRNAs [130].

SnoRNAs are also involved in the onset of the Prader-Willy syndrome (PWS), induced by the genetic loss of the 15q11-q13 locus, normally active only on the paternal allele. This site is characterized by several copies of the HBII-85 snoRNA, whose loss seems to be correlated with the PWS phenotype, both in human and in mice [131,132]. Moreover, recent studies reported the involvement of snoRNAs in cancer formation and progression, although the exact molecular mechanisms by which snoRNAs regulate cancer are still unknown.

Similarly to miRNAs, snoRNA expression has been found deregulated in cancer patient samples. In fact, the expression of GAS5 (growth arrest specific 5), a gene which encodes an lncRNA but also harbors ten intronic snoRNAs, is downregulated in breast cancer compared to normal adjacent epithelial breast tissue. GAS5 transcript sensitizes mammalian cells to apoptosis inducers, therefore displaying a tumor-suppressor role [133]. Moreover, Nakamura and coworkers demonstrated that GAS5 was a partner of BCL6 in a patient with diffuse large B-cell lymphoma, carrying the chromosomal translocation $\mathrm{t}(1 ; 3)$ (q25; q27) [134], while Gee showed that GAS5 low expression correlated with poor prognosis in breast cancer and head and neck squamous carcinoma [135]. The same authors also reported that snoRNA U50 is frequently transcriptionally downregulated in breast and prostate cancer [136] and that its 2-nucleotides somatic and germline deletion led to increased incidence of homozygosity for the deletion in cancer cells.

Other snoRNAs, such as snoRNA42, overexpressed in NSCLC cells, are located at frequently amplified genomic regions in tumors, therefore acting like oncogenes and promoting tumor growth. In 2011 Mei and coworkers found that snoRNA42 knockdown in NSCLC cells impaired tumorigenicity in vitro and in vivo promoting apoptosis in a p53-dependent manner; conversely its enforced expression in bronchial epitheliums promoted cell growth [137].

Moreover, Liao et al. performed a profiling study on 22 NSCLC tissues. They found an overexpression of six snoRNAs compared to normal specimens. In addition to snoRNA42, they 
identified SNORD33, SNORD66, SNORD73B, SNORD76 and SNORD78. Of these, SNORD33, SNORD66, and SNORD76 expression in the plasma of NSCLC patients was higher compared to cancer-free individuals [138]. It has been demonstrated that, in addition to deregulated snoRNAs, also mutations of genes encoding for snoRNPs (snoRNA-associated proteins) can promote tumorigenesis. One of these genes is the human dyskerin, a putative pseudouridine synthase involved in the rRNA pseudouridylation and in the stabilization of the telomerase RNA elements. Mutations of its gene, $D K C 1$, cause the $\mathrm{X}$-linked genetic disease dyskeratosis congenita and promote tumor formation in mice [139]. The same effects have been described when point mutations occur in the genes encoding NOP10 and NHP2, both components of the H/ACA snoRNPs.

Figure 3. Intronic snoRNA processing. SnoRNA maturation occurs through two distinct pathways: splicing-dependent and splicing-independent. In the first pathway, the splicing of a pre-mRNA leads to a snoRNA-containing lariat, which is linearized by the enzyme Dbrlp and then endonucleases and exonucleases release the mature snoRNA. In the splicing-independent pathway the snoRNA is directly excided from the intron of the pre-mRNA by endonucleolytic cleavage.

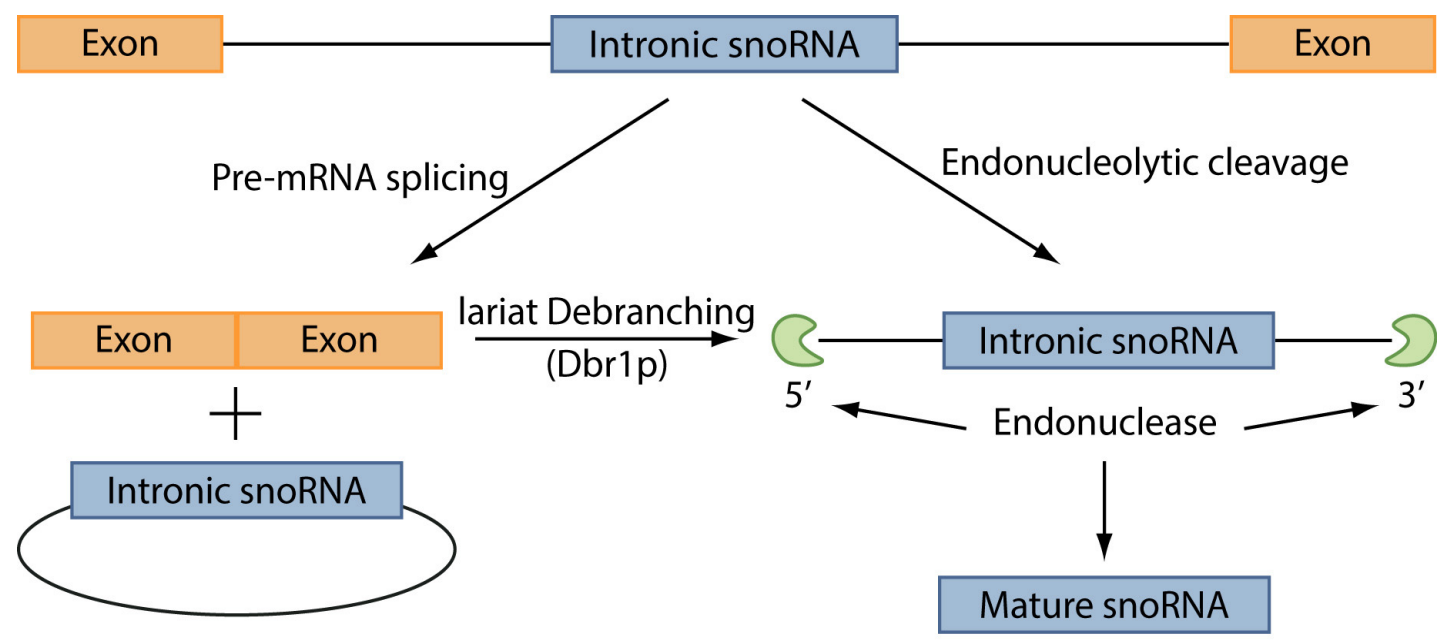

\section{Long Noncoding RNAs}

Several studies based on RNA deep sequencing and genome-wide analysis have recently pointed out that the genome of mammals, as well of other organisms, contains thousands of long transcripts whose length ranges from $200 \mathrm{nt}$ to 100 kilobases, called long non-coding RNAs (lncRNAs or lincRNA, for long intergenic ncRNA) [3,140-144]. LncRNAs are located within nuclear or cytosolic fractions [145]. They are usually transcribed by RNA polymerase II but have no open reading frame [146], and map to intronic and intergenic regions [147]. Moreover, they display epigenetic features common to protein-coding genes, such as trimethylation of histone 3 lysine 4 (H3K4me3) at the transcriptional start site (TSS), and trimethylation of histone 3 lysine 36 (H3K36me3) throughout the gene body $[148,149]$. It has been estimated that nearly 15,000 lncRNAs are present in the human genome, but only a small fraction is expressed in a given cell type. All the information regarding identified IncRNAs has been catalogued and is available at the website http://www.lncrnadb.org [150-152]. 
Although they were initially thought to be the product of a "noisy" inconsequential transcription resulting from low RNA polymerase fidelity [142], recent studies have demonstrated that lncRNAs regulate several biological processes such as transcription [153-156], translation [157], cellular differentiation [158], regulation of gene expression [159], cell cycle regulation [160,161], chromatin modification [143,162,163], and nuclear-cytoplasmic trafficking [159,164-167].

LncRNAs have been also found to guide protein complexes which regulate chromatin modification or transcription to their targets $[143,162,168,169]$. Finally, it has been demonstrated that lncRNAs are dysregulated in several human diseases, including cancer.

Dysregulated expression of lncRNAs in cancer marks the spectrum of disease progression [170] and may serve as an independent predictor for patient outcomes [171].

Long non-coding RNAs can mediate epigenetic changes by recruiting chromatin-remodeling complexes to specific genomic loci. A recent study found that $20 \%$ of 3300 human long non coding RNAs are bound by Polycomb Repressive Complex 2 (PRC2) [162]. Although the specific molecular mechanisms are not defined, there are several examples that illustrate the silencing potential of lncRNAs. The first, most known example is represented by Xist (X-inactive-specific transcript) gene, which encodes an IncRNA crucial for the inactivation of the X-chromosome in mammals [172]. Basically, Xist physically coats one of the two X-chromosomes and recruits the chromatin regulator PRC2 (Polycomb chromatin remodeling complex) to this chromosome, promoting the formation of heterochromatin through histone modifications [173]. Another important example is represented by the hundreds of long ncRNAs which are sequentially expressed in the human homeobox (Hox) loci, where they define chromatin domains of differential histone methylation and RNA polymerase accessibility [174]. One of these ncRNAs, Hox transcript antisense RNA (HOTAIR) regulates in trans human $H O X D$ genes expression through the induction of a repressive chromatin state. This occurs through the association of HOTAIR with the chromatin-modifying complexes PRC2, LSD1, and coREST/REST $[143,162,171]$. As modulator of epigenetic landmark, it has been shown that HOTAIR has a profound effect on tumorigenesis. Indeed, it is upregulated in breast and colon cancers and it is associated with metastasis and poor prognosis [171]. Another important effect of lncRNAs on chromatin modification with important consequences in cancer is represented by the lncRNA ANRIL, which controls the epigenetic status of the locus INK4b/ARF/INK4a by interacting with subunits of PRC1 and PRC2. High expression of ANRIL has been found in some cancer tissues such as melanoma and prostate cancers $([175,176]$. The long noncoding RNA MALAT1 (metastasis-associated lung adenocarcinoma transcript 1), also known as NEAT2 (nuclear-enriched abundant transcript 2), is a highly conserved nuclear noncoding RNA (ncRNA) which acts as molecular decoy serving as a structural link in ribonucleoprotein (RNPs) complexes. Gutschner and colleagues developed a MALAT1 knockout model in human lung tumor cells. In lung cancer, MALAT1 does not alter alternative splicing but actively regulates gene expression including a set of metastasis-associated genes. Consequently, MALAT1-deficient cells are impaired in migration and form fewer tumor nodules in a mouse xenograft. Antisense oligonucleotides (ASO), blocking MALAT1, prevent metastasis formation after tumor implantation [177]. In addition to these active lncRNAs acting as oncogenes, there are also lncRNAs with tumor suppressor function. One very famous example is the ncRNA GAS5 (Growth Arrest-Specific 5). It was originally identified based on its increased levels in growth-arrested mouse NIH3T3 fibroblasts [132]. GAS5 binds to the DNA-binding domain of the 
glucocorticoid receptor (GR) by acting as a decoy glucocorticoid response element (GRE), thus competing with DNA GREs for binding to the GR [156]. GAS5 negatively regulates the survival of lymphoid and breast cells, and is aberrantly expressed in several cancers. Pickard et al. showed that GAS5 promotes apoptosis of prostate cells after irradiation with UV-C light and low levels of GAS5 expression may therefore reduce the effectiveness of chemotherapeutic agents [178].

Recently, lncRNAs have also shown their tumorigenic potential by modulating the transcriptional program of $\mathrm{p} 53$ [179].

A $3 \mathrm{~kb} \operatorname{lncRNA}$, linc-RNA-p21, transcriptionally activated by $\mathrm{p} 53$, has been shown to collaborate with p53 in order to control gene expression in response to DNA damage. Silencing of lincRNA-p21 derepresses the expression of hundreds of genes through the interaction with hnRNP-K (Heterogeneous nuclear ribonucleoprotein $\mathrm{K}$ ), thus, promoting apoptosis of abnormal cells or restraining tumors [179].

LncRNA $P A N D A$ is induced in response to external stimuli in a p53-dependent manner. After DNA damage p53 directly binds to the $C D K N 1 A$ locus and activates $P A N D A$, which enables cell-cycle arrest and impairs the expression of pro-apoptotic genes thanks to its interaction with the transcription factor NF-YA [LNC8] [180].

In addition to the features described above, recent studies have unveiled other properties of lncRNAs. For instance, it has been demonstrated that pseudogene transcripts are biologically active as they can regulate mRNA stability. One example is given by the tumor suppressor pseudogene PTENP1, whose 3' UTR region is very similar to the untraslated region of PTEN transcript. Both these regions bind the same set of miRNAs, and PTENP1 pseudogene may act as "decoy" by protecting PTEN mRNA from common miRNA binding and allowing the expression of the tumor suppressor protein. PTENP1 pseudogene therefore belongs to the group of competing endogenous RNAs (ceRNAs). Similarly, KRAS and KRASIP transcript levels have been found positively correlated, corroborating that pseudogene functions mirror the role of their cognate genes as explained by a miRNA decoy mechanism. In cancer, specific mutations at the binding site of these pseudogenes impair their activity, therefore promoting tumor progression [181].

Enhancer-like lncRNAs (eRNAs) were discovered by Ørom and colleagues in 2010 [141]. The authors used a GENCODE annotation of the human genome to characterize over a thousand lncRNAs in several cell lines, finding that some of these RNAs displayed an enhancer-like function. Depletion of these ncRNAs led to a decreased expression of their neighboring protein-codon genes, such as the regulator of hematopoiesis SCL, Snail, and Snai2, indicating that eRNAs play a pivotal role in development and differentiation. Moreover, Melo et al. showed through genome-wide chromatin-binding profiles that $\mathrm{p} 53$ protein binds also to regions located at distant sites from any known p53 target gene. Such regions were characterized not only by conserved p53-binding sites but displayed also enhancer activity and interacted with multiple neighboring genes allowing long-distance p53-dependent transcription regulation [182].

Finally, Natural Antisense Transcripts (NATs) are a large class of lncRNA transcribed from the opposite DNA strand to other transcripts and overlap in part with sense RNA. NATs play an important role in antisense regulation in gene expression. NATs have been implicated in several processes such as RNA translation [183] and transcriptional interference [184], and they have a pivotal role also in cancer. $a H I F$, a NAT derived from the 3' UTR of HIF1, represents the first case of overexpression of a 
NAT associated with a specific human malignant disease: non-papillary clear-cell renal carcinomas, but not in papillary renal carcinomas [185]. Moreover, it has been demonstrated that $a H I F$ expression is a poor prognosis marker in breast cancer [186].

The already mentioned $A N R I L$ is an antisense lncRNA originates from the INK4B-ARF-INK4A locus, which contains three tumour suppressor genes, and it is overexpressed in prostate cancer tissues. Repression of $A N R I L$ expression was associated with a reduction in cellular proliferation and increased the expression of both $\mathrm{p} 16^{\mathrm{Ink} 4 \mathrm{~A}}$ and $\mathrm{p} 15^{\mathrm{INK} 4 \mathrm{~B}}$, which are encoded by $C D K N 2 A$ and $C D K N 2 B$, respectively [176]. BOKAS is a natural antisense transcript of Bok, a proapoptotic member in the Bcl-2 family. The expression of $B O K A S$ was only detected in testis and different cancer tissues but not in other normal adult tissues. Overexpression of BOKAS was able to inhibit Bok-induced apoptosis in HeLa cells [187].

Another example of NAT is represented by Zeb2/Sip1 NAT. This NAT regulates E-cadherin expression by increasing the levels of Zeb2 protein, a transcriptional repressor of E-cadherin, suggesting a role for noncoding RNAs in the control of epithelial morphology [188].

\section{Conclusions}

The recent discoveries regarding the biogenesis and function of ncRNAs have definitely improved our undestanding of the complexity of the human genome and the regulation of several processes. In particular, the involvement of microRNAs in the regulation of cell cycle, proliferation, differentiation and, most of all, in cancer formation and progression has certainly opened new fields of research aimed to better elucidate their mechanisms of action. Recently, our group reported that miRNAs secreted through exosomes bind to Toll-like receptor 8 (TLR8) in human and TLR7 in mouse inducing a pro-inflammatory response [189]. Therefore, in addition to their post-transcriptional regulatory function, miRNAs act like hormones and are involved into cell-to-cell communication. Other studies have shown the presence of tumor-derived microRNAs in serum or plasma as an approach for blood-based detection of human cancers, indicating that microRNAs could be used as circulating biomarkers [190]. Several groups are currently investigating the possibility to use microRNAs as therapeutic tools alone or in combination with chemotherapy.

Successfull systemic delivery of miRNAs as anti-cancer approaches in preclinical models using liposomes [191], viral vectors [192], and nanoparticles [193] has been reported. There is no doubt that miRNAs and other ncRNAs play a very important role in the regulation of pathways involved in tumor development and progression. Although there are still several obstacles to overcome before clinical testing of miRNA therapeutics, such as delivery and chemical modification of miRNA modulators, the fact that ncRNAs are natural antisense interactors and regulate many genes involved in survival and proliferation makes them excellent candidates to become powerful therapeutic tools in the near future.

\section{Acknowledgements}

We thank Justin Middleton for editorial assistance. Michela Garofalo is recipient of the Kimmel Award. 


\section{Conflicts of Interest}

The authors declare no conflict of interests.

\section{References}

1. International Human Genome Sequencing Consortium. Finishing the euchromatic sequence of the human genome. Nature 2004, 431, 931-945.

2. Kapranov, P.; Cheng, J.; Dike, S.; Nix, D.A.; Duttagupta, R.; Willingham, A.T.; Stadler, P.F.; Hertel, J.; Hackermuller, J.; Hofacker, I.L.; et al. RNA maps reveal new RNA classes and a possible function for pervasive transcription. Science 2007, 316, 1484-1488.

3. Carninci, P.; Kasukawa, T.; Katayama, S.; Gough, J.; Frith, M.C.; Maeda, N.; Oyama, R.; Ravasi, T.; Lenhard, B.; Wells, C.; et al. The transcriptional landscape of the mammalian genome. Science 2005, 309, 1559-1563.

4. Senti, K.A.; Brennecke, J. The piRNA pathway: A fly's perspective on the guardian of the genome. Trends Genet. 2010, 26, 499-509.

5. Vagin, V.V.; Sigova, A.; Li, C.; Seitz, H.; Gvozdev, V.; Zamore, P.D. A distinct small RNA pathway silences selfish genetic elements in the germline. Science 2006, 313, 320-324.

6. Brennecke, J.; Aravin, A.A.; Stark, A.; Dus, M.; Kellis, M.; Sachidanandam, R.; Hannon, G.J. Discrete small RNA-generating loci as master regulators of transposon activity in drosophila. Cell 2007, 128, 1089-1103.

7. Houwing, S.; Kamminga, L.M.; Berezikov, E.; Cronembold, D.; Girard, A.; van den Elst, H.; Filippov, D.V.; Blaser, H.; Raz, E.; Moens, C.B.; et al. A role for piwi and piRNAs in germ cell maintenance and transposon silencing in zebrafish. Cell 2007, 129, 69-82.

8. Kuramochi-Miyagawa, S.; Kimura, T.; Ijiri, T.W.; Isobe, T.; Asada, N.; Fujita, Y.; Ikawa, M.; Iwai, N.; Okabe, M.; Deng, W.; et al. Mili, a mammalian member of piwi family gene, is essential for spermatogenesis. Development 2004, 131, 839-849.

9. Deng, W.; Lin, H. Miwi, a murine homolog of piwi, encodes a cytoplasmic protein essential for spermatogenesis. Dev. Cell 2002, 2, 819-830.

10. Carmell, M.A.; Girard, A.; van de Kant, H.J.; Bourc'his, D.; Bestor, T.H.; de Rooij, D.G.; Hannon, G.J. Miwi2 is essential for spermatogenesis and repression of transposons in the mouse male germline. Dev. Cell 2007, 12, 503-514.

11. Sasaki, T.; Shiohama, A.; Minoshima, S.; Shimizu, N. Identification of eight members of the argonaute family in the human genome small star, filled. Genomics 2003, 82, 323-330.

12. Chen, Y.; Pane, A.; Schupbach, T. Cutoff and aubergine mutations result in retrotransposon upregulation and checkpoint activation in drosophila. Curr. Biol. 2007, 17, 637-642.

13. Cox, D.N.; Chao, A.; Baker, J.; Chang, L.; Qiao, D.; Lin, H. A novel class of evolutionarily conserved genes defined by piwi are essential for stem cell self-renewal. Genes Dev. 1998, 12, 3715-3727.

14. Houwing, S.; Berezikov, E.; Ketting, R.F. Zili is required for germ cell differentiation and meiosis in zebrafish. EMBO 2008, 27, 2702-2711. 
15. Schupbach, T.; Wieschaus, E. Female sterile mutations on the second chromosome of drosophila melanogaster. II. mutations blocking oogenesis or altering egg morphology. Genetics 1991, 129, 1119-1136.

16. Aravin, A.; Gaidatzis, D.; Pfeffer, S.; Lagos-Quintana, M.; Landgraf, P.; Iovino, N.; Morris, P.; Brownstein, M.J.; Kuramochi-Miyagawa, S.; Nakano, T.; et al. A novel class of small RNAs bind to MILI protein in mouse testes. Nature 2006, 442, 203-207.

17. Girard, A.; Sachidanandam, R.; Hannon, G.J.; Carmell, M.A. A germline-specific class of small RNAs binds mammalian Piwi proteins. Nature 2006, 442, 199-202.

18. Grivna, S.T.; Beyret, E.; Wang, Z.; Lin, H. A novel class of small RNAs in mouse spermatogenic cells. Genes Dev. 2006, 20, 1709-1714.

19. Watanabe, T.; Takeda, A.; Tsukiyama, T.; Mise, K.; Okuno, T.; Sasaki, H.; Minami, N.; Imai, H. Identification and characterization of two novel classes of small RNAs in the mouse germline: Retrotransposon-derived siRNAs in oocytes and germline small RNAs in testes. Genes Dev. 2006, 20, 1732-1743.

20. Das, P.P.; Bagijn, M.P.; Goldstein, L.D.; Woolford, J.R.; Lehrbach, N.J.; Sapetschnig, A.; Buhecha, H.R.; Gilchrist, M.J.; Howe, K.L.; Stark, R.; et al. Piwi and piRNAs act upstream of an endogenous siRNA pathway to suppress tc 3 transposon mobility in the Caenorhabditis elegans germline. Mol. Cell 2008, 31, 79-90.

21. Horwich, M.D.; Li, C.; Matranga, C.; Vagin, V.; Farley, G.; Wang, P.; Zamore, P.D. The drosophila RNA methyltransferase, dmhen1, modifies germline piRNAs and single-stranded siRNAs in risc. Curr. Biol. 2007, 17, 1265-1272.

22. Saito, K.; Sakaguchi, Y.; Suzuki, T.; Suzuki, T.; Siomi, H.; Siomi, M.C. Pimet, the drosophila homolog of hen1, mediates 2'-O-methylation of piwi-interacting RNAs at their $3^{\prime}$ ends. Genes Dev. 2007, 21, 1603-1608.

23. Kirino, Y.; Mourelatos, Z. Mouse piwi-interacting RNAs are 2'-O-methylated at their 3 ' termini. Nat. Struct. Mol. Biol. 2007, 14, 347-348.

24. Nishimasu, H.; Ishizu, H.; Saito, K.; Fukuhara, S.; Kamatani, M.K.; Bonnefond, L.; Matsumoto, N.; Nishizawa, T.; Nakanaga, K.; Aoki, J.; et al. Structure and function of zucchini endoribonuclease in piRNA biogenesis. Nature 2012, 491, 284-287.

25. Saito, K.; Ishizu, H.; Komai, M.; Kotani, H.; Kawamura, Y.; Nishida, K.M.; Siomi, H.; Siomi, M.C. Roles for the $\mathrm{Yb}$ body components armitage and $\mathrm{Yb}$ in primary piRNA biogenesis in drosophila. Genes Dev. 2010, 24, 2493-2498.

26. Le Thomas, A.; Rogers, A.K.; Webster, A.; Marinov, G.K.; Liao, S.E.; Perkins, E.M.; Hur, J.K.; Aravin, A.A.; Toth, K.F. Piwi induces piRNA-guided transcriptional silencing and establishment of a repressive chromatin state. Genes Dev. 2013, 27, 390-399.

27. Rozhkov, N.V.; Hammell, M.; Hannon, G.J. Multiple roles for piwi in silencing drosophila transposons. Genes Dev. 2013, 27, 400-412.

28. Lee, E.J.; Banerjee, S.; Zhou, H.; Jammalamadaka, A.; Arcila, M.; Manjunath, B.S.; Kosik, K.S. Identification of piRNAs in the central nervous system. RNA (New York, N.Y.) 2011, 17, 1090-1099. 
29. Yan, Z.; Hu, H.Y.; Jiang, X.; Maierhofer, V.; Neb, E.; He, L.; Hu, Y.; Hu, H.; Li, N.; Chen, W.; et al. Widespread expression of piRNA-like molecules in somatic tissues. Nucleic Acids Res. 2011, 39, 6596-6607.

30. Lu, Y.; Li, C.; Zhang, K.; Sun, H.; Tao, D.; Liu, Y.; Zhang, S.; Ma, Y. Identification of piRNAs in hela cells by massive parallel sequencing. BMB Rep.2010, 43, 635-641.

31. Cheng, J.; Guo, J.M.; Xiao, B.X.; Miao, Y.; Jiang, Z.; Zhou, H.; Li, Q.N. PiRNA, the new non-coding RNA, is aberrantly expressed in human cancer cells. Clin. Chim. Acta 2011, 412, $1621-1625$.

32. Qiao, D.; Zeeman, A.M.; Deng, W.; Looijenga, L.H.; Lin, H. Molecular characterization of hiwi, a human member of the piwi gene family whose overexpression is correlated to seminomas. Oncogene 2002, 21, 3988-3999.

33. Grochola, L.F.; Greither, T.; Taubert, H.; Moller, P.; Knippschild, U.; Udelnow, A.; Henne-Bruns, D.; Wurl, P. The stem cell-associated hiwi gene in human adenocarcinoma of the pancreas: Expression and risk of tumour-related death. Br. J. Cancer 2008, 99, 1083-1088.

34. He, W.; Wang, Z.; Wang, Q.; Fan, Q.; Shou, C.; Wang, J.; Giercksky, K.E.; Nesland, J.M.; Suo, Z. Expression of hiwi in human esophageal squamous cell carcinoma is significantly associated with poorer prognosis. BMC Cancer 2009, 9, 426.

35. Liu, W.K.; Jiang, X.Y.; Zhang, Z.X. Expression of psca, piwill, and tbx2 in endometrial adenocarcinoma. Onkologie 2010, 33, 241-245.

36. Liu, W.K.; Jiang, X.Y.; Zhang, Z.X. Expression of psca, piwill and $t b \times 2$ and its correlation with hpvl6 infection in formalin-fixed, paraffin-embedded cervical squamous cell carcinoma specimens. Arch. Virol. 2010, 155, 657-663.

37. Sun, G.; Wang, Y.; Sun, L.; Luo, H.; Liu, N.; Fu, Z.; You, Y. Clinical significance of hiwi gene expression in gliomas. Brain Res. 2011, 1373, 183-188.

38. Zeng, Y.; Qu, L.K.; Meng, L.; Liu, C.Y.; Dong, B.; Xing, X.F.; Wu, J.; Shou, C.C. Hiwi expression profile in cancer cells and its prognostic value for patients with colorectal cancer. Chin. Med. J. 2011, 124, 2144-2149.

39. Zhao, Y.M.; Zhou, J.M.; Wang, L.R.; He, H.W.; Wang, X.L.; Tao, Z.H.; Sun, H.C.; Wu, W.Z.; Fan, J.; Tang, Z.Y.; et al. Hiwi is associated with prognosis in patients with hepatocellular carcinoma after curative resection. Cancer 2012, 118, 2708-2717.

40. Cheng, J.; Deng, H.; Xiao, B.; Zhou, H.; Zhou, F.; Shen, Z.; Guo, J. PiR-823, a novel non-coding small RNA, demonstrates in vitro and in vivo tumor suppressive activity in human gastric cancer cells. Cancer Lett. 2012, 315, 12-17.

41. Cui, L.; Lou, Y.; Zhang, X.; Zhou, H.; Deng, H.; Song, H.; Yu, X.; Xiao, B.; Wang, W.; Guo, J. Detection of circulating tumor cells in peripheral blood from patients with gastric cancer using piRNAs as markers. Clin. Biochem. 2011, 44, 1050-1057.

42. Lee, R.C.; Feinbaum, R.L.; Ambros, V. The C. elegans heterochronic gene lin-4 encodes small RNAs with antisense complementarity to lin-14. Cell 1993, 75, 843-854.

43. Bartel, D.P. MicroRNAs: Genomics, biogenesis, mechanism, and function. Cell 2004, 116, 281-297.

44. Denli, A.M.; Tops, B.B.; Plasterk, R.H.; Ketting, R.F.; Hannon, G.J. Processing of primary microRNAs by the microprocessor complex. Nature 2004, 432, 231-235. 
45. Lagos-Quintana, M.; Rauhut, R.; Lendeckel, W.; Tuschl, T. Identification of novel genes coding for small expressed RNAs. Science 2001, 294, 853-858.

46. Lee, R.C.; Ambros, V. An extensive class of small RNAs in Caenorhabditis elegans. Science 2001, 294, 862-864.

47. Hu, W.; Chan, C.S.; Wu, R.; Zhang, C.; Sun, Y.; Song, J.S.; Tang, L.H.; Levine, A.J.; Feng, Z. Negative regulation of tumor suppressor p53 by microRNA miR-504. Mol. Cell 2010, 38, 689-699.

48. Bagga, S.; Bracht, J.; Hunter, S.; Massirer, K.; Holtz, J.; Eachus, R.; Pasquinelli, A.E. Regulation by let-7 and lin-4 miRNAs results in target mRNA degradation. Cell 2005, 122, 553-563.

49. Harfe, B.D. MicroRNAs in vertebrate development. Curr. Opin. Genet. Dev. 2005, 15, 410-415.

50. Boehm, M.; Slack, F.J. MicroRNA control of lifespan and metabolism. Cell Cycle 2006, 5, 837-840.

51. Calin, G.A.; Garzon, R.; Cimmino, A.; Fabbri, M.; Croce, C.M. MicroRNAs and leukemias: How strong is the connection? Leuk. Res. 2006, 30, 653-655.

52. Arisawa, T.; Tahara, T.; Shibata, T.; Nagasaka, M.; Nakamura, M.; Kamiya, Y.; Fujita, H.; Hasegawa, S.; Takagi, T.; Wang, F.Y.; et al. A polymorphism of microRNA $27 a$ genome region is associated with the development of gastric mucosal atrophy in japanese male subjects. Dig. Dis. Sci. 2007, 52, 1691-1697.

53. Carleton, M.; Cleary, M.A.; Linsley, P.S. MicroRNAs and cell cycle regulation. Cell Cycle 2007, 6, 2127-2132.

54. Lee, Y.; Kim, M.; Han, J.; Yeom, K.H.; Lee, S.; Baek, S.H.; Kim, V.N. MicroRNA genes are transcribed by RNA polymerase ii. EMBO 2004, 23, 4051-4060.

55. Cai, X.; Hagedorn, C.H.; Cullen, B.R. Human microRNAs are processed from capped, polyadenylated transcripts that can also function as mRNAs. RNA (New York, N.Y.) 2004, 10, 1957-1966.

56. Ambros, V. The functions of animal microRNAs. Nature 2004, 431, 350-355.

57. Bohnsack, M.T.; Czaplinski, K.; Gorlich, D. Exportin 5 is a rangtp-dependent dsRNA-binding protein that mediates nuclear export of pre-miRNAs. RNA (New York, N.Y.) 2004, 10, 185-191.

58. Esquela-Kerscher, A.; Johnson, S.M.; Bai, L.; Saito, K.; Partridge, J.; Reinert, K.L.; Slack, F.J. Post-embryonic expression of $C$. elegans microRNAs belonging to the lin-4 and let-7 families in the hypodermis and the reproductive system. Dev. Dyn. 2005, 234, 868-877.

59. Achard, P.; Herr, A.; Baulcombe, D.C.; Harberd, N.P. Modulation of floral development by a gibberellin-regulated microRNA. Development 2004, 131, 3357-3365.

60. Gregory, R.I.; Chendrimada, T.P.; Shiekhattar, R. MicroRNA biogenesis: Isolation and characterization of the microprocessor complex. Methods Mol. Biol. 2006, 342, 33-47.

61. Calin, G.A.; Dumitru, C.D.; Shimizu, M.; Bichi, R.; Zupo, S.; Noch, E.; Aldler, H.; Rattan, S.; Keating, M.; Rai, K.; et al. Frequent deletions and down-regulation of micro-RNA genes miR15 and miRl6 at 13q14 in chronic lymphocytic leukemia. Proc. Natl. Acad. Sci. USA 2002, 99, 15524-15529.

62. Calin, G.A.; Ferracin, M.; Cimmino, A.; Di Leva, G.; Shimizu, M.; Wojcik, S.E.; Iorio, M.V.; Visone, R.; Sever, N.I.; Fabbri, M.; et al. A microRNA signature associated with prognosis and progression in chronic lymphocytic leukemia. N. Engl. J. Med. 2005, 353, 1793-1801. 
63. Nakamura, T.; Canaani, E.; Croce, C.M. Oncogenic all1 fusion proteins target drosha-mediated microRNA processing. Proc. Natl. Acad. Sci. USA 2007, 104, 10980-10985.

64. Saito, Y.; Liang, G.; Egger, G.; Friedman, J.M.; Chuang, J.C.; Coetzee, G.A.; Jones, P.A. Specific activation of microRNA-127 with downregulation of the proto-oncogene bcl6 by chromatin-modifying drugs in human cancer cells. Cancer Cell 2006, 9, 435-443.

65. Fabbri, M.; Croce, C.M.; Calin, G.A. MicroRNAs. Cancer J. 2008, 14, 1-6.

66. Garzon, R.; Volinia, S.; Liu, C.G.; Fernandez-Cymering, C.; Palumbo, T.; Pichiorri, F.; Fabbri, M.; Coombes, K.; Alder, H.; Nakamura, T.; et al. MicroRNA signatures associated with cytogenetics and prognosis in acute myeloid leukemia. Blood 2008, 111, 3183-3189.

67. Ciafre, S.A.; Galardi, S.; Mangiola, A.; Ferracin, M.; Liu, C.G.; Sabatino, G.; Negrini, M.; Maira, G.; Croce, C.M.; Farace, M.G. Extensive modulation of a set of microRNAs in primary glioblastoma. Biochem. Biophys. Res. Commun. 2005, 334, 1351-1358.

68. Volinia, S.; Calin, G.A.; Liu, C.G.; Ambs, S.; Cimmino, A.; Petrocca, F.; Visone, R.; Iorio, M.; Roldo, C.; Ferracin, M.; et al. A microRNA expression signature of human solid tumors defines cancer gene targets. Proc. Natl. Acad. Sci. USA 2006, 103, 2257-2261.

69. Asangani, I.A.; Rasheed, S.A.; Nikolova, D.A.; Leupold, J.H.; Colburn, N.H.; Post, S.; Allgayer, H. MicroRNA-21 (miR-21) post-transcriptionally downregulates tumor suppressor pdcd4 and stimulates invasion, intravasation and metastasis in colorectal cancer. Oncogene 2008, 27, 2128-2136.

70. Zhang, J.G.; Wang, J.J.; Zhao, F.; Liu, Q.; Jiang, K.; Yang, G.H. MicroRNA-21 (miR-21) represses tumor suppressor pten and promotes growth and invasion in non-small cell lung cancer (nsclc). Clin. Chim. Acta 2010, 411, 846-852.

71. Quintavalle, C.; Donnarumma, E.; Iaboni, M.; Roscigno, G.; Garofalo, M.; Romano, G.; Fiore, D.; De Marinis, P.; Croce, C.M.; Condorelli, G. Effect of $m i R-21$ and $m i R-30 b / c$ on trail-induced apoptosis in glioma cells. Oncogene 2012, doi:10.1038/onc.2012.410.

72. Kluiver, J.; Poppema, S.; de Jong, D.; Blokzijl, T.; Harms, G.; Jacobs, S.; Kroesen, B.J.; van den Berg, A. Bic and miR-155 are highly expressed in hodgkin, primary mediastinal and diffuse large B cell lymphomas. J. Pathol. 2005, 207, 243-249.

73. Calin, G.A.; Cimmino, A.; Fabbri, M.; Ferracin, M.; Wojcik, S.E.; Shimizu, M.; Taccioli, C.; Zanesi, N.; Garzon, R.; Aqeilan, R.I.; et al. Mir-15a and miR-16-1 cluster functions in human leukemia. Proc. Natl. Acad. Sci. USA 2008, 105, 5166-5171.

74. Jiang, S.; Zhang, H.W.; Lu, M.H.; He, X.H.; Li, Y.; Gu, H.; Liu, M.F.; Wang, E.D. MicroRNA-155 functions as an oncomir in breast cancer by targeting the suppressor of cytokine signaling 1 gene. Cancer Res. 2010, 70, 3119-3127.

75. Ovcharenko, D.; Kelnar, K.; Johnson, C.; Leng, N.; Brown, D. Genome-scale microRNA and small interfering RNA screens identify small RNA modulators of trail-induced apoptosis pathway. Cancer Res. 2007, 67, 10782-10788.

76. Costinean, S.; Zanesi, N.; Pekarsky, Y.; Tili, E.; Volinia, S.; Heerema, N.; Croce, C.M. Pre-B cell proliferation and lymphoblastic leukemia/high-grade lymphoma in $e(m u)$-miR155 transgenic mice. Proc. Natl. Acad. Sci. USA 2006, 103, 7024-7029. 
77. Fornari, F.; Gramantieri, L.; Ferracin, M.; Veronese, A.; Sabbioni, S.; Calin, G.A.; Grazi, G.L.; Giovannini, C.; Croce, C.M.; Bolondi, L.; et al. Mir-221 controls cdkn1c/p57 and cdkn1b/p27 expression in human hepatocellular carcinoma. Oncogene 2008, 27, 5651-5661.

78. Di Leva, G.; Gasparini, P.; Piovan, C.; Ngankeu, A.; Garofalo, M.; Taccioli, C.; Iorio, M.V.; Li, M.; Volinia, S.; Alder, H.; et al. MicroRNA cluster 221-222 and estrogen receptor alpha interactions in breast cancer. J. Natl. Cancer Inst. 2010, 102, 706-721.

79. Felicetti, F.; Errico, M.C.; Bottero, L.; Segnalini, P.; Stoppacciaro, A.; Biffoni, M.; Felli, N.; Mattia, G.; Petrini, M.; Colombo, M.P.; et al. The promyelocytic leukemia zinc finger-microRNA-221/-222 pathway controls melanoma progression through multiple oncogenic mechanisms. Cancer Res. 2008, 68, 2745-2754.

80. Pallante, P.; Visone, R.; Ferracin, M.; Ferraro, A.; Berlingieri, M.T.; Troncone, G.; Chiappetta, G.; Liu, C.G.; Santoro, M.; Negrini, M.; et al. MicroRNA deregulation in human thyroid papillary carcinomas. Endovr.-Relat. Cancer 2006, 13, 497-508.

81. le Sage, C.; Nagel, R.; Egan, D.A.; Schrier, M.; Mesman, E.; Mangiola, A.; Anile, C.; Maira, G.; Mercatelli, N.; Ciafre, S.A.; et al. Regulation of the p27(kip1) tumor suppressor by $m i R-221$ and miR-222 promotes cancer cell proliferation. EMBO 2007, 26, 3699-3708.

82. Garofalo, M.; Quintavalle, C.; Di Leva, G.; Zanca, C.; Romano, G.; Taccioli, C.; Liu, C.G.; Croce, C.M.; Condorelli, G. MicroRNA signatures of trail resistance in human non-small cell lung cancer. Oncogene 2008, 27, 3845-3855.

83. Quintavalle, C.; Garofalo, M.; Zanca, C.; Romano, G.; Iaboni, M.; del Basso De Caro, M.; Martinez-Montero, J.C.; Incoronato, M.; Nuovo, G.; Croce, C.M.; et al. MiR-221/222 overexpession in human glioblastoma increases invasiveness by targeting the protein phosphate ptpmu. Oncogene 2012, 31, 858-868.

84. Garofalo, M.; Di Leva, G.; Romano, G.; Nuovo, G.; Suh, S.S.; Ngankeu, A.; Taccioli, C.; Pichiorri, F.; Alder, H.; Secchiero, P.; et al. Mir-221 \& 222 regulate trail resistance and enhance tumorigenicity through pten and timp3 downregulation. Cancer Cell 2009, 16, 498-509.

85. Manni, I.; Artuso, S.; Careccia, S.; Rizzo, M.G.; Baserga, R.; Piaggio, G.; Sacchi, A. The microRNA miR-92 increases proliferation of myeloid cells and by targeting p63 modulates the abundance of its isoforms. FASEB 2009, 23, 3957-3966.

86. Voorhoeve, P.M.; le Sage, C.; Schrier, M.; Gillis, A.J.; Stoop, H.; Nagel, R.; Liu, Y.P.; van Duijse, J.; Drost, J.; Griekspoor, A.; et al. A genetic screen implicates miRNA-372 and miRNA-373 as oncogenes in testicular germ cell tumors. Cell 2006, 124, 1169-1181.

87. Ma, L.; Teruya-Feldstein, J.; Weinberg, R.A. Tumour invasion and metastasis initiated by microRNA-10b in breast cancer. Nature 2007, 449, 682-688.

88. Petrocca, F.; Visone, R.; Onelli, M.R.; Shah, M.H.; Nicoloso, M.S.; de Martino, I.; Iliopoulos, D.; Pilozzi, E.; Liu, C.G.; Negrini, M.; et al. E2f1-regulated microRNAs impair tgfbeta-dependent cell-cycle arrest and apoptosis in gastric cancer. Cancer Cell 2008, 13, 272-286.

89. Cimmino, A.; Calin, G.A.; Fabbri, M.; Iorio, M.V.; Ferracin, M.; Shimizu, M.; Wojcik, S.E.; Aqeilan, R.I.; Zupo, S.; Dono, M.; et al. MiR-15 and miR-16 induce apoptosis by targeting $b c l 2$. Proc. Natl. Acad. Sci. USA 2005, 102, 13944-13949. 
90. Bonci, D.; Coppola, V.; Musumeci, M.; Addario, A.; Giuffrida, R.; Memeo, L.; D'Urso, L.; Pagliuca, A.; Biffoni, M.; Labbaye, C.; et al. The miR-15a-miR-16-1 cluster controls prostate cancer by targeting multiple oncogenic activities. Nat. Med. 2008, 14, 1271-1277.

91. Bhattacharya, R.; Nicoloso, M.; Arvizo, R.; Wang, E.; Cortez, A.; Rossi, S.; Calin, G.A.; Mukherjee, P. MiR-15a and miR-16 control bmi-1 expression in ovarian cancer. Cancer Res. 2009, 69, 9090-9095.

92. Sun, C.Y.; She, X.M.; Qin, Y.; Chu, Z.B.; Chen, L.; Ai, L.S.; Zhang, L.; Hu, Y. MiR-15a and miR-16 affect the angiogenesis of multiple myeloma by targeting vegf. Carcinogenesis 2013, 34, 426-435.

93. Pouliot, L.M.; Chen, Y.C.; Bai, J.; Guha, R.; Martin, S.E.; Gottesman, M.M.; Hall, M.D. Cisplatin sensitivity mediated by weel and chk 1 is mediated by $m i R-155$ and the $m i R-15$ family. Cancer Res. 2012, 72, 5945-5955.

94. Takamizawa, J.; Konishi, H.; Yanagisawa, K.; Tomida, S.; Osada, H.; Endoh, H.; Harano, T.; Yatabe, Y.; Nagino, M.; Nimura, Y.; et al. Reduced expression of the let-7 microRNAs in human lung cancers in association with shortened postoperative survival. Cancer Res. 2004, 64, 3753-3756.

95. Zhang, H.H.; Wang, X.J.; Li, G.X.; Yang, E.; Yang, N.M. Detection of let-7a microRNA by real-time PCR in gastric carcinoma. World J. Gastroenterol. 2007, 13, 2883-2888.

96. Akao, Y.; Nakagawa, Y.; Naoe, T. Let-7 microRNA functions as a potential growth suppressor in human colon cancer cells. Biol. Pharm. Bull. 2006, 29, 903-906.

97. Sampson, V.B.; Rong, N.H.; Han, J.; Yang, Q.; Aris, V.; Soteropoulos, P.; Petrelli, N.J.; Dunn, S.P.; Krueger, L.J. MicroRNA let-7a down-regulates myc and reverts myc-induced growth in burkitt lymphoma cells. Cancer Res. 2007, 67, 9762-9770.

98. Johnson, S.M.; Grosshans, H.; Shingara, J.; Byrom, M.; Jarvis, R.; Cheng, A.; Labourier, E.; Reinert, K.L.; Brown, D.; Slack, F.J. Ras is regulated by the let-7 microRNA family. Cell 2005, 120, 635-647.

99. Mayr, C.; Hemann, M.T.; Bartel, D.P. Disrupting the pairing between let-7 and hmga2 enhances oncogenic transformation. Science 2007, 315, 1576-1579.

100. Wang, Y.; Lu, Y.; Toh, S.T.; Sung, W.K.; Tan, P.; Chow, P.; Chung, A.Y.; Jooi, L.L.; Lee, C.G. Lethal-7 is down-regulated by the hepatitis B virus $\mathrm{x}$ protein and targets signal transducer and activator of transcription 3. J. Hepatol. 2010, 53, 57-66.

101. Hu, X.; Guo, J.; Zheng, L.; Li, C.; Zheng, T.M.; Tanyi, J.L.; Liang, S.; Benedetto, C.; Mitidieri, M.; Katsaros, D.; et al. The heterochronic microRNA let-7 inhibits cell motility by regulating the genes in the actin cytoskeleton pathway in breast cancer. Mol. Cancer Res. 2013, $11,240-250$.

102. Wiggins, J.F.; Ruffino, L.; Kelnar, K.; Omotola, M.; Patrawala, L.; Brown, D.; Bader, A.G. Development of a lung cancer therapeutic based on the tumor suppressor microRNA-34. Cancer Res. 2010, 70, 5923-5930.

103. Li, N.; Fu, H.; Tie, Y.; Hu, Z.; Kong, W.; Wu, Y.; Zheng, X. Mir-34a inhibits migration and invasion by down-regulation of c-met expression in human hepatocellular carcinoma cells. Cancer Lett. 2009, 275, 44-53. 
104. Lodygin, D.; Tarasov, V.; Epanchintsev, A.; Berking, C.; Knyazeva, T.; Korner, H.; Knyazev, P.; Diebold, J.; Hermeking, H. Inactivation of $m i R-34 a$ by aberrant $\mathrm{CpG}$ methylation in multiple types of cancer. Cell Cycle 2008, 7, 2591-2600.

105. Tazawa, H.; Tsuchiya, N.; Izumiya, M.; Nakagama, H. Tumor-suppressive miR-34a induces senescence-like growth arrest through modulation of the e2f pathway in human colon cancer cells. Proc. Natl. Acad. Sci. USA 2007, 104, 15472-15477.

106. Welch, C.; Chen, Y.; Stallings, R.L. MicroRNA-34a functions as a potential tumor suppressor by inducing apoptosis in neuroblastoma cells. Oncogene 2007, 26, 5017-5022.

107. Corney, D.C.; Hwang, C.I.; Matoso, A.; Vogt, M.; Flesken-Nikitin, A.; Godwin, A.K.; Kamat, A.A.; Sood, A.K.; Ellenson, L.H.; Hermeking, H.; et al. Frequent downregulation of miR-34 family in human ovarian cancers. Clin. Cancer Res. 2010, 16, 1119-1128.

108. Chen, X.; Hu, H.; Guan, X.; Xiong, G.; Wang, Y.; Wang, K.; Li, J.; Xu, X.; Yang, K.; Bai, Y. $\mathrm{CpG}$ island methylation status of miRNAs in esophageal squamous cell carcinoma. Int. J. Cancer 2012, 130, 1607-1613.

109. Mraz, M.; Malinova, K.; Kotaskova, J.; Pavlova, S.; Tichy, B.; Malcikova, J.; Stano Kozubik, K.; Smardova, J.; Brychtova, Y.; Doubek, M.; et al. Mir-34a, miR-29c and miR-17-5p are downregulated in cll patients with tp53 abnormalities. Leukemia 2009, 23, 1159-1163.

110. He, L.; He, X.; Lim, L.P.; de Stanchina, E.; Xuan, Z.; Liang, Y.; Xue, W.; Zender, L.; Magnus, J.; Ridzon, D.; et al. A microRNA component of the p53 tumour suppressor network. Nature 2007, 447, 1130-1134.

111. Garofalo, M.; Jeon, Y.J.; Nuovo, G.J.; Middleton, J.; Secchiero, P.; Joshi, P.; Alder, H.; Nazaryan, N.; Di Leva, G.; Romano, G.; et al. Mir-34a/c-dependent pdgfr-alpha/beta downregulation inhibits tumorigenesis and enhances trail-induced apoptosis in lung cancer. PLoS One 2013, 8, e67581.

112. Park, S.M.; Gaur, A.B.; Lengyel, E.; Peter, M.E. The $m i R-200$ family determines the epithelial phenotype of cancer cells by targeting the e-cadherin repressors zeb1 and zeb2. Genes Dev. 2008, 22, 894-907.

113. Liu, S.; Tetzlaff, M.T.; Cui, R.; Xu, X. Mir-200c inhibits melanoma progression and drug resistance through down-regulation of bmi-1. Am. J. Pathol. 2012, 181, 1823-1835.

114. Iorio, M.V.; Ferracin, M.; Liu, C.G.; Veronese, A.; Spizzo, R.; Sabbioni, S.; Magri, E.; Pedriali, M.; Fabbri, M.; Campiglio, M.; et al. MicroRNA gene expression deregulation in human breast cancer. Cancer Res. 2005, 65, 7065-7070.

115. Li, Y.; Wang, F.; Xu, J.; Ye, F.; Shen, Y.; Zhou, J.; Lu, W.; Wan, X.; Ma, D.; Xie, X. Progressive miRNA expression profiles in cervical carcinogenesis and identification of $h p v$-related target genes for miR-29. J. Pathol. 2011, 224, 484-495.

116. Xiong, Y.; Fang, J.H.; Yun, J.P.; Yang, J.; Zhang, Y.; Jia, W.H.; Zhuang, S.M. Effects of microRNA-29 on apoptosis, tumorigenicity, and prognosis of hepatocellular carcinoma. Hepatology 2010, 51, 836-845.

117. Fabbri, M.; Garzon, R.; Cimmino, A.; Liu, Z.; Zanesi, N.; Callegari, E.; Liu, S.; Alder, H.; Costinean, S.; Fernandez-Cymering, C.; et al. MicroRNA-29 family reverts aberrant methylation in lung cancer by targeting DNA methyltransferases 3 a and 3b. Proc. Natl. Acad. Sci. USA 2007, 104, 15805-15810. 
118. Pekarsky, Y.; Santanam, U.; Cimmino, A.; Palamarchuk, A.; Efanov, A.; Maximov, V.; Volinia, S.; Alder, H.; Liu, C.G.; Rassenti, L.; et al. Tcll expression in chronic lymphocytic leukemia is regulated by miR-29 and miR-181. Cancer Res. 2006, 66, 11590-11593.

119. Mott, J.L.; Kobayashi, S.; Bronk, S.F.; Gores, G.J. Mir-29 regulates mcl-1 protein expression and apoptosis. Oncogene 2007, 26, 6133-6140.

120. Zhang, X.; Zhao, X.; Fiskus, W.; Lin, J.; Lwin, T.; Rao, R.; Zhang, Y.; Chan, J.C.; Fu, K.; Marquez, V.E.; et al. Coordinated silencing of $m y c$-mediated miR-29 by hdac3 and ezh2 as a therapeutic target of histone modification in aggressive B-cell lymphomas. Cancer Cell 2012, 22, $506-523$.

121. Smith, C.M.; Steitz, J.A. Sno storm in the nucleolus: New roles for myriad small rnps. Cell 1997, 89, 669-672.

122. Bortolin, M.L.; Kiss, T. Human u19 intron-encoded snoRNA is processed from a long primary transcript that possesses little potential for protein coding. RNA (New York, N.Y.) 1998, 4, 445-454.

123. Kiss-Laszlo, Z.; Henry, Y.; Bachellerie, J.P.; Caizergues-Ferrer, M.; Kiss, T. Site-specific ribose methylation of preribosomal RNA: A novel function for small nucleolar RNAs. Cell 1996, 85, 1077-1088.

124. Lafontaine, D.L.; Tollervey, D. Birth of the snornps: The evolution of the modification-guide snoRNAs. Trends Biochem. Sci. 1998, 23, 383-388.

125. Terns, M.P.; Terns, R.M. Small nucleolar RNAs: Versatile trans-acting molecules of ancient evolutionary origin. Gene Expr. 2002, 10, 17-39.

126. Weinstein, L.B.; Steitz, J.A. Guided tours: From precursor snoRNA to functional snornp. Curr. Opin. Cell Biol. 1999, 11, 378-384.

127. Kiss, A.M.; Jady, B.E.; Bertrand, E.; Kiss, T. Human box h/aca pseudouridylation guide RNA machinery. Mol. Cell. Biol. 2004, 24, 5797-5807.

128. Bachellerie, J.P.; Cavaille, J.; Huttenhofer, A. The expanding snoRNA world. Biochimie 2002, 84, 775-790.

129. Coughlin, D.J.; Pleiss, J.A.; Walker, S.C.; Whitworth, G.B.; Engelke, D.R. Genome-wide search for yeast RNase $\mathrm{p}$ substrates reveals role in maturation of intron-encoded box $\mathrm{c} / \mathrm{d}$ small nucleolar RNAs. Proc. Natl. Acad. Sci. USA 2008, 105, 12218-12223.

130. Brameier, M.; Herwig, A.; Reinhardt, R.; Walter, L.; Gruber, J. Human box c/d snoRNAs with miRNA like functions: Expanding the range of regulatory RNAs. Nucleic Acids Res. 2011, 39, 675-686.

131. Li, R.; Wang, H.; Bekele, B.N.; Yin, Z.; Caraway, N.P.; Katz, R.L.; Stass, S.A.; Jiang, F. Identification of putative oncogenes in lung adenocarcinoma by a comprehensive functional genomic approach. Oncogene 2006, 25, 2628-2635.

132. Schneider, C.; King, R.M.; Philipson, L. Genes specifically expressed at growth arrest of mammalian cells. Cell 1988, 54, 787-793.

133. Mourtada-Maarabouni, M.; Pickard, M.R.; Hedge, V.L.; Farzaneh, F.; Williams, G.T. Gas5, a non-protein-coding RNA, controls apoptosis and is downregulated in breast cancer. Oncogene 2009, 28, 195-208. 
134. Nakamura, Y.; Takahashi, N.; Kakegawa, E.; Yoshida, K.; Ito, Y.; Kayano, H.; Niitsu, N.; Jinnai, I.; Bessho, M. The gas5 (growth arrest-specific transcript 5) gene fuses to bcl6 as a result of $\mathrm{t}(1 ; 3)$ (q25; q27) in a patient with B-cell lymphoma. Cancer Genet. Cytogenet. 2008, 182, $144-149$.

135. Gee, H.E.; Buffa, F.M.; Camps, C.; Ramachandran, A.; Leek, R.; Taylor, M.; Patil, M.; Sheldon, H.; Betts, G.; Homer, J.; et al. The small-nucleolar RNAs commonly used for microRNA normalisation correlate with tumour pathology and prognosis. Br. J. Cancer 2011, 104, 1168-1177.

136. Tanaka, R.; Satoh, H.; Moriyama, M.; Satoh, K.; Morishita, Y.; Yoshida, S.; Watanabe, T.; Nakamura, Y.; Mori, S. Intronic u50 small-nucleolar-RNA (snoRNA) host gene of no protein-coding potential is mapped at the chromosome breakpoint $\mathrm{t}(3 ; 6)(\mathrm{q} 27 ; \mathrm{q} 15)$ of human B-cell lymphoma. Genes Cells 2000, 5, 277-287.

137. Mei, Y.P.; Liao, J.P.; Shen, J.; Yu, L.; Liu, B.L.; Liu, L.; Li, R.Y.; Ji, L.; Dorsey, S.G.; Jiang, Z.R.; et al. Small nucleolar RNA 42 acts as an oncogene in lung tumorigenesis. Oncogene 2012, 31, 2794-2804.

138. Liao, J.; Yu, L.; Mei, Y.; Guarnera, M.; Shen, J.; Li, R.; Liu, Z.; Jiang, F. Small nucleolar RNA signatures as biomarkers for non-small-cell lung cancer. Mol. Cancer 2010, 9, 198.

139. Ruggero, D.; Grisendi, S.; Piazza, F.; Rego, E.; Mari, F.; Rao, P.H.; Cordon-Cardo, C.; Pandolfi, P.P. Dyskeratosis congenita and cancer in mice deficient in ribosomal RNA modification. Science 2003, 299, 259-262.

140. Cabili, M.N.; Trapnell, C.; Goff, L.; Koziol, M.; Tazon-Vega, B.; Regev, A.; Rinn, J.L. Integrative annotation of human large intergenic noncoding RNAs reveals global properties and specific subclasses. Genes Dev. 2011, 25, 1915-1927.

141. Orom, U.A.; Derrien, T.; Beringer, M.; Gumireddy, K.; Gardini, A.; Bussotti, G.; Lai, F.; Zytnicki, M.; Notredame, C.; Huang, Q.; et al. Long noncoding RNAs with enhancer-like function in human cells. Cell 2010, 143, 46-58.

142. Ponting, C.P.; Oliver, P.L.; Reik, W. Evolution and functions of long noncoding RNAs. Cell 2009, 136, 629-641.

143. Khalil, A.M.; Guttman, M.; Huarte, M.; Garber, M.; Raj, A.; Rivea Morales, D.; Thomas, K.; Presser, A.; Bernstein, B.E.; van Oudenaarden, A.; et al. Many human large intergenic noncoding RNAs associate with chromatin-modifying complexes and affect gene expression. Proc. Natl. Acad. Sci. USA 2009, 106, 11667-11672.

144. Guttman, M.; Amit, I.; Garber, M.; French, C.; Lin, M.F.; Feldser, D.; Huarte, M.; Zuk, O.; Carey, B.W.; Cassady, J.P.; et al. Chromatin signature reveals over a thousand highly conserved large non-coding RNAs in mammals. Nature 2009, 458, 223-227.

145. Birney, E.; Stamatoyannopoulos, J.A.; Dutta, A.; Guigo, R.; Gingeras, T.R.; Margulies, E.H.; Weng, Z.; Snyder, M.; Dermitzakis, E.T.; Thurman, R.E.; et al. Identification and analysis of functional elements in $1 \%$ of the human genome by the encode pilot project. Nature 2007, 447, 799-816.

146. Brosnan, C.A.; Voinnet, O. The long and the short of noncoding RNAs. Curr. Opin. Cell Biol. 2009, 21, 416-425. 
147. Amaral, P.P.; Mattick, J.S. Noncoding RNA in development. Mamm. Genome 2008, 19, 454-492.

148. Pang, K.C.; Frith, M.C.; Mattick, J.S. Rapid evolution of noncoding RNAs: Lack of conservation does not mean lack of function. Trends Genet. 2006, 22, 1-5.

149. Chen, L.L.; Carmichael, G.G. Decoding the function of nuclear long non-coding RNAs. Curr. Opin. Cell Biol. 2010, 22, 357-364.

150. Amaral, P.P.; Clark, M.B.; Gascoigne, D.K.; Dinger, M.E.; Mattick, J.S. Lncrnadb: A reference database for long noncoding RNAs. Nucleic Acids Res. 2011, 39, D146-D151.

151. Dinger, M.E.; Pang, K.C.; Mercer, T.R.; Crowe, M.L.; Grimmond, S.M.; Mattick, J.S. NRED: A database of long noncoding RNA expression. Nucleic Acids Res. 2009, 37, D122-D126.

152. Derrien, T.; Johnson, R.; Bussotti, G.; Tanzer, A.; Djebali, S.; Tilgner, H.; Guernec, G.; Martin, D.; Merkel, A.; Knowles, D.G.; et al. The gencode v7 catalog of human long noncoding RNAs: Analysis of their gene structure, evolution, and expression. Genome Res. 2012, 22, 1775-1789.

153. Wang, X.; Arai, S.; Song, X.; Reichart, D.; Du, K.; Pascual, G.; Tempst, P.; Rosenfeld, M.G.; Glass, C.K.; Kurokawa, R. Induced ncRNAs allosterically modify RNA-binding proteins in cis to inhibit transcription. Nature 2008, 454, 126-130.

154. Schwartz, J.C.; Younger, S.T.; Nguyen, N.B.; Hardy, D.B.; Monia, B.P.; Corey, D.R.; Janowski, B.A. Antisense transcripts are targets for activating small RNAs. Nat. Struct. Mol. Biol. 2008, 15, 842-848.

155. Tasheva, E.S.; Roufa, D.J. Regulation of human rps 14 transcription by intronic antisense RNAs and ribosomal protein s14. Genes Dev. 1995, 9, 304-316.

156. Kino, T.; Hurt, D.E.; Ichijo, T.; Nader, N.; Chrousos, G.P. Noncoding RNA gas5 is a growth arrest- and starvation-associated repressor of the glucocorticoid receptor. Science Signal. 2010, 3, doi:10.1126/scisignal.2000568.

157. Lin, D.; Pestova, T.V.; Hellen, C.U.; Tiedge, H. Translational control by a small RNA: Dendritic bc1 RNA targets the eukaryotic initiation factor 4a helicase mechanism. Mol. Cell. Biol. 2008, 28, 3008-3019.

158. Young, T.L.; Matsuda, T.; Cepko, C.L. The noncoding RNA taurine upregulated gene 1 is required for differentiation of the murine retina. Curr. Biol. 2005, 15, 501-512.

159. Wang, K.C.; Chang, H.Y. Molecular mechanisms of long noncoding RNAs. Mol. Cell 2011, 43, 904-914.

160. Yochum, G.S.; Cleland, R.; McWeeney, S.; Goodman, R.H. An antisense transcript induced by wnt/beta-catenin signaling decreases e2f4. J. Biol. Chem. 2007, 282, 871-878.

161. Mourtada-Maarabouni, M.; Hedge, V.L.; Kirkham, L.; Farzaneh, F.; Williams, G.T. Growth arrest in human t-cells is controlled by the non-coding RNA growth-arrest-specific transcript 5 (gas5). J. Cell Sci. 2008, 121, 939-946.

162. Rinn, J.L.; Kertesz, M.; Wang, J.K.; Squazzo, S.L.; Xu, X.; Brugmann, S.A.; Goodnough, L.H.; Helms, J.A.; Farnham, P.J.; Segal, E.; et al. Functional demarcation of active and silent chromatin domains in human hox loci by noncoding RNAs. Cell 2007, 129, 1311-1323.

163. Yu, W.; Gius, D.; Onyango, P.; Muldoon-Jacobs, K.; Karp, J.; Feinberg, A.P.; Cui, H. Epigenetic silencing of tumour suppressor gene $p 15$ by its antisense RNA. Nature 2008, 451, 202-206. 
164. Mercer, T.R.; Dinger, M.E.; Mattick, J.S. Long non-coding RNAs: Insights into functions. Nat. Rev. Genet. 2009, 10, 155-159.

165. Nagano, T.; Fraser, P. No-nonsense functions for long noncoding RNAs. Cell 2011, 145, 178-181.

166. Clark, M.B.; Mattick, J.S. Long noncoding RNAs in cell biology. Semin. Cell Dev. Biol. 2011, 22, 366-376.

167. Mattick, J.S.; Amaral, P.P.; Dinger, M.E.; Mercer, T.R.; Mehler, M.F. RNA regulation of epigenetic processes. BioEssays 2009, 31, 51-59.

168. Nagano, T.; Mitchell, J.A.; Sanz, L.A.; Pauler, F.M.; Ferguson-Smith, A.C.; Feil, R.; Fraser, P. The air noncoding RNA epigenetically silences transcription by targeting g9a to chromatin. Science 2008, 322, 1717-1720.

169. Pandey, R.R.; Mondal, T.; Mohammad, F.; Enroth, S.; Redrup, L.; Komorowski, J.; Nagano, T.; Mancini-Dinardo, D.; Kanduri, C. Kcnq1ot1 antisense noncoding RNA mediates lineage-specific transcriptional silencing through chromatin-level regulation. Mol. Cell 2008, 32, 232-246.

170. Prensner, J.R.; Iyer, M.K.; Balbin, O.A.; Dhanasekaran, S.M.; Cao, Q.; Brenner, J.C.; Laxman, B.; Asangani, I.A.; Grasso, C.S.; Kominsky, H.D.; et al. Transcriptome sequencing across a prostate cancer cohort identifies pcat-1, an unannotated lincRNA implicated in disease progression. Nat. Biotechnol. 2011, 29, 742-749.

171. Gupta, R.A.; Shah, N.; Wang, K.C.; Kim, J.; Horlings, H.M.; Wong, D.J.; Tsai, M.C.; Hung, T.; Argani, P.; Rinn, J.L.; et al. Long non-coding RNA hotair reprograms chromatin state to promote cancer metastasis. Nature 2010, 464, 1071-1076.

172. Lee, J.T. Gracefully ageing at 50, X-chromosome inactivation becomes a paradigm for RNA and chromatin control. Nat. Rev. Mol. Cell Biol. 2011, 12, 815-826.

173. Zhao, J.; Sun, B.K.; Erwin, J.A.; Song, J.J.; Lee, J.T. Polycomb proteins targeted by a short repeat RNA to the mouse x chromosome. Science 2008, 322, 750-756.

174. Morris, K.V.; Santoso, S.; Turner, A.M.; Pastori, C.; Hawkins, P.G. Bidirectional transcription directs both transcriptional gene activation and suppression in human cells. PLoS Genet. 2008, 4, e1000258.

175. Vanneste, R.; Smith, E.; Graham, G. Multiple neurofibromas as the presenting feature of familial atypical multiple malignant melanoma (fammm) syndrome. Am. J. Med. Genet. 2013, 161, 1425-1431.

176. Yap, K.L.; Li, S.; Munoz-Cabello, A.M.; Raguz, S.; Zeng, L.; Mujtaba, S.; Gil, J.; Walsh, M.J.; Zhou, M.M. Molecular interplay of the noncoding RNA anril and methylated histone h3 lysine 27 by polycomb cbx7 in transcriptional silencing of ink4a. Mol. Cell 2010, 38, 662-674.

177. Gutschner, T.; Hammerle, M.; Eissmann, M.; Hsu, J.; Kim, Y.; Hung, G.; Revenko, A.; Arun, G.; Stentrup, M.; Gross, M.; et al. The noncoding RNA malat1 is a critical regulator of the metastasis phenotype of lung cancer cells. Cancer Res. 2013, 73, 1180-1189.

178. Pickard, M.R.; Mourtada-Maarabouni, M.; Williams, G.T. Long non-coding RNA gas5 regulates apoptosis in prostate cancer cell lines. Biochim. Biophys. Acta 2013, 1832, 1613-1623.

179. Huarte, M.; Guttman, M.; Feldser, D.; Garber, M.; Koziol, M.J.; Kenzelmann-Broz, D.; Khalil, A.M.; Zuk, O.; Amit, I.; Rabani, M.; et al. A large intergenic noncoding RNA induced by p53 mediates global gene repression in the $p 53$ response. Cell 2010, 142, 409-419. 
180. Hung, T.; Wang, Y.; Lin, M.F.; Koegel, A.K.; Kotake, Y.; Grant, G.D.; Horlings, H.M.; Shah, N.; Umbricht, C.; Wang, P.; et al. Extensive and coordinated transcription of noncoding RNAs within cell-cycle promoters. Nat. Genet. 2011, 43, 621-629.

181. Poliseno, L.; Salmena, L.; Zhang, J.; Carver, B.; Haveman, W.J.; Pandolfi, P.P. A coding-independent function of gene and pseudogene mRNAs regulates tumour biology. Nature 2010, 465, 1033-1038.

182. Melo, C.A.; Drost, J.; Wijchers, P.J.; van de Werken, H.; de Wit, E.; Oude Vrielink, J.A.; Elkon, R.; Melo, S.A.; Leveille, N.; Kalluri, R.; et al. ERNAs are required for $p 53$-dependent enhancer activity and gene transcription. Mol. Cell 2013, 49, 524-535.

183. Brantl, S. Antisense-RNA regulation and RNA interference. Biochim. Biophys. Acta 2002, 1575, 15-25.

184. Prescott, E.M.; Proudfoot, N.J. Transcriptional collision between convergent genes in budding yeast. Proc. Natl. Acad. Sci. USA 2002, 99, 8796-8801.

185. Thrash-Bingham, C.A.; Tartof, K.D. Ahif: A natural antisense transcript overexpressed in human renal cancer and during hypoxia. J. Natl. Cancer Inst. 1999, 91, 143-151.

186. Cayre, A.; Rossignol, F.; Clottes, E.; Penault-Llorca, F. Ahif but not hif-1alpha transcript is a poor prognostic marker in human breast cancer. Breast Cancer Res. 2003, 5, R223-230.

187. Zhang, H.; Gao, S.; De Geyter, C. A natural antisense transcript, bokas, regulates the pro-apoptotic activity of human bok. Int. J. Oncol. 2009, 34, 1135-1138.

188. Beltran, M.; Puig, I.; Pena, C.; Garcia, J.M.; Alvarez, A.B.; Pena, R.; Bonilla, F.; de Herreros, A.G. A natural antisense transcript regulates zeb2/sipl gene expression during snaill-induced epithelial-mesenchymal transition. Genes Dev. 2008, 22, 756-769.

189. Fabbri, M.; Paone, A.; Calore, F.; Galli, R.; Gaudio, E.; Santhanam, R.; Lovat, F.; Fadda, P.; Mao, C.; Nuovo, G.J.; et al. MicroRNAs bind to toll-like receptors to induce prometastatic inflammatory response. Proc. Natl. Acad. Sci. USA 2012, 109, E2110-2116.

190. Mitchell, P.S.; Parkin, R.K.; Kroh, E.M.; Fritz, B.R.; Wyman, S.K.; Pogosova-Agadjanyan, E.L.; Peterson, A.; Noteboom, J.; O'Briant, K.C.; Allen, A.; et al. Circulating microRNAs as stable blood-based markers for cancer detection. Proc. Natl. Acad. Sci. USA 2008, 105, 10513-10518.

191. Rai, K.; Takigawa, N.; Ito, S.; Kashihara, H.; Ichihara, E.; Yasuda, T.; Shimizu, K.; Tanimoto, M.; Kiura, K. Liposomal delivery of microRNA-7-expressing plasmid overcomes epidermal growth factor receptor tyrosine kinase inhibitor-resistance in lung cancer cells. Mol. Cancer Ther. 2011, 10, 1720-1727.

192. Kota, J.; Chivukula, R.R.; O'Donnell, K.A.; Wentzel, E.A.; Montgomery, C.L.; Hwang, H.W.; Chang, T.C.; Vivekanandan, P.; Torbenson, M.; Clark, K.R.; et al. Therapeutic microRNA delivery suppresses tumorigenesis in a murine liver cancer model. Cell 2009, 137, 1005-1017.

193. Su, J.; Baigude, H.; McCarroll, J.; Rana, T.M. Silencing microRNA by interfering nanoparticles in mice. Nucleic Acids Res. 2011, 39, e38.

(C) 2013 by the authors; licensee MDPI, Basel, Switzerland. This article is an open access article distributed under the terms and conditions of the Creative Commons Attribution license (http://creativecommons.org/licenses/by/3.0/). 